\title{
PERSUASIVE STRATEGIES IN WOMAN COSMETICS ADVERTISEMENT OF SKIN WHITENING PRODUCT ON TELEVISION COMMERCIAL
}

\author{
AN ARTICLE \\ Submitted in Partial Fulfillment of the Requirements \\ for the Degree of Sarjana Sastra
}

By:

DEWI ANJANI PURBA

Reg. Number: 2133220008

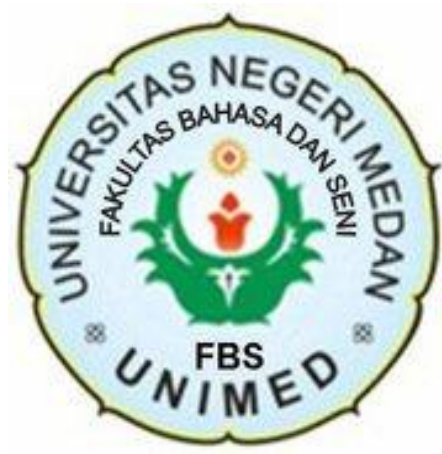

ENGLISH AND LITERATURE DEPARTMENTS

FACULTY OF LANGUAGES AND ARTS

STATE UNIVERSITY OF MEDAN

2017 


\section{ARTIKEL \\ PERSUASIVE STRATEGIES IN WOMAN COSMETICS ADVERTISEMENT OF SKIN WHITENING PRODUCT ON TELEVISION COMMERCIAL}

Disusun dan Diajukan oleh:

Dewi Anjani Purba

NIM. 2133220008

Telah diverifikasi dan dinyatakan memenuhi syarat untuk diunggah pada jurnal online

Medan, Juli 2017

Menyetujui

Dosen Pembimbing Skripsi I

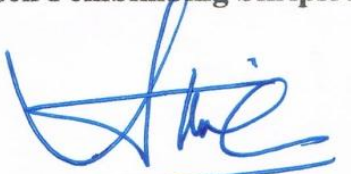

Prof. Dr. Hj. Sumarsih, M.Pd NIP. 195810211983032002
Dosen Pembimbing Skripsi II

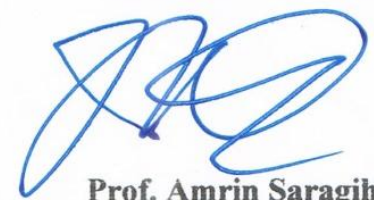

Prof. Amrin Saragih, M.A, Ph.D NIP. 195501131982031002

Ketua Prodi Sastra Inggris

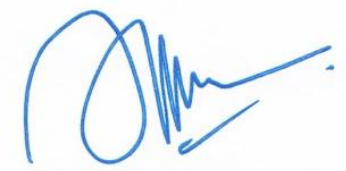

Juli Rachmadani Hasibuan, S.S, M.Hum.

NIP. 198207112008012008 


\title{
PERSUASIVE STRATEGIES IN WOMAN COSMETICS \\ ADVERTISEMENT OF SKIN WHITENING PRODUCT ON TELEVISION \\ COMMERCIAL
}

*Dewi Anjani Purba

** Prof. Dr. Hj. Sumarsih, M.Pd.

*** Prof. Amrin Saragih, M.A, Ph.D.

\begin{abstract}
Purba, DewiAnjani. 2133220008. Persuasive Strategies In Woman Cosmetics Advertisement Of Skin Whitening Product On Television Commercial. A Thesis. English and Literature Department. Faculty of Languages and Arts. State University of Medan. 2017.

This research is aimed at describing persuasive strategies in woman cosmetics advertisement, elaborating the ways of the strategies are used and investigating the reason for the use of strategies. The study is based on a descriptive qualitative method, The researcher analyzed through describing and explaining data based on persuasive strategies by Aristotle (1854). There are about 50 samples of woman cosmetics in skin whitening product from different brand. Those advertisements are in the form of video taken from the official website of the product, youtube, and watching the advertisement in television. The result of this study found that there were 32 utterances that categorized as Ethos, 12 as Pathos, and 6 as Logos. There are two process happen in this persuasive strategies, The Elaboration Likelihood Model (Central \& Peripheral Route) and Heuristic Systematic Model (Heuristically Processing \& Systematically Processing). Central Route 31, Peripheral Route 19. HeuristicallyProcessing 12 and Systematically Processing 38. Reasons for the use of Central Route in the advertisement should be relevant, any facts. Peripheral Route, irrelevant, and no fact. Heuristically Processing, message by expert or endorse by artist, not always giving facts. Systematically Processing, relevant, motivate the costumers, any facts.

Keywords : Aristotle, Persuasive Strategies, Woman Cosmetics, Advertisement.
\end{abstract}

\footnotetext{
*Graduate Status

** Lecturer Status
} 


\section{INTRODUCTION}

\section{Background of the study}

Topic about the use of language is the object study of Discourse Analysis. This study related to linguistics, such as how languages used in persuading people during communication. Process aimed at changing a person's (or a group's) attitude or behavior toward some event, idea, object, or other person(s), by using written or spoken words to convey information ,feelings, or reasoning, or a combination of them (Aristotle 1854). Mostly the aim of communication is persuasion.Persuasive is a form of rhetoric. It is a communicative act that carries out both these goals an audience that has been persuaded has understood an utterance, and believed its message. Let rhetoric be defined as an ability, in each particular case, to the available means of persuasion, this is the function of no other art; for each of the other is instructive and persuasive about its own subject (Aristotle).

Media became the most part of important thing while using language. Media become popular as an effective way to be in touch with public. Television is one of helpful communication medium which presented any kind of information, news, entertainments such as film, music, and education. As its character, television has superiority in the sound and picture which the public more interest in this media so they can receive the information optimally. 
Advertisement in this modern era can be found everywhere such as on the television, magazine, newspaper, on the road, attached on the wall or trees, on the supermarket and another place. Nowadays, people cannot live separately with advertisement.

One of favorite products or service in society which presents in television are woman cosmetics. Cosmetics, also known as make-up, are substances or products used to enhance or alter the appearance or fragrance of the body. Many cosmetics are designed for use of applying to the face, body and hair. They are generally mixtures of chemical compounds; some being derived from natural sources (such as coconut oil), and some being synthetics.

Furthermore, the researcher uses Aristotle's theory which provides three kinds of persuasive strategies to help the researcher get the comprehensive understanding about woman cosmetics television commercial. The purpose of this research are to find out thekinds of persuasive strategies are used in woman cosmetics advertisement on television programs, How are the strategies of persuasive techniques used in woman cosmetics advertisement on television programs and why are the strategies used is the ways they are.

This study has some differences with another research journals. The objects of previous study were about the speech, promotion strategies of the products, technique, slogans of the products, and the text in the advertisement. While in this study, the researcher is going to analyzed all the utterances from the advertisement of skin whitening product on television commercials. Another difference is about the focus of object that wanted to analyze. The researcher will analyze about fifty advertisements of skin whitening products from different brands according to Aristotle theory of persuasion that divided into three kinds of persuasive strategies, that are Ethos, Pathos and Logos.

\section{REVIEW OF LITERATURE}

One of the study of language is called as Discourse analysis. The word "discourse" is usually defined as a language beyond the sentence. The meaning of sentence was not literary stated, but it was implicitly. While discourse analysis, as 
Yule (2006) defined is branches of linguistics study which concerned on the study of language in the text and conversation. Discourse analysis is study of language which is used and arranged inside the cultural and political context as a place where the discourse occurs..

Discourse analysis takes a significant role in human communication since it is not only focuses on the language and the meaning but deeply to the some elements in communication, such as how, who, what, and when the language is used. It is in line with Brown and Yule (1983) who argued Discourse analysis is committed to an investigation of what and how that language is used for. McCarthy (2001) stated, " Discourse analysis study language in use are written texts of all kinds, spoken data, from conversation to highly institutionalized forms of talk". It can be said that discourse analysis concern both in spoken and written data, either exist in mass media or other source.

In this research, persuasive discourse is the main focus of the writer's discussion. Persuasive almost found in advertisement as an effective way to introduce product and service to the costumer. While creating an advertisement, advertiser should use a correct technique to attract the customers intention, remember there are a lot of product which also promotes through television's commercial.

Persuasive strategies is the way of persuading people by to do or believe something. The modes of persuasive strategies according to Aristotle furnished by the spoken word there are three kinds. The first kind depends on the personal character of the speaker [ethos], the second on putting the audience into a certain frame of mind [pathos], the third on the proof, or apparent proof, provided by the words of the speech itself [logos]. Persuasion is achieved by the speaker's personal character when the sentences make us think that it is true and credible.Persuasive in the advertisement is oneexample of the uses persuasion. The advertiser always used some strategies to persuade the consumers.Aristotle (1854) defined that they are three strategies to persuade the consumers attention. They are Ethos, Pathos and Logos. 
Ethos: an appeal to credibility or character. An advertisement using ethos will try to convince you that the company is more reliable, honest, and credible; therefore, you should buy its product. Pathos: an appeal to emotion. An advertisement using pathos will attempt to evoke an emotional response in the consumer. Logos: an appeal to logic or reason. An advertisement using logos will give you the evidence and statistics you need to fully understand what the product does.

Blech (2003) stated that "Advertising is one of the elements of the communication strategy of a brand, together with other instruments such as public relations, sales force, merchandising, promotions, sponsorship and direct marketing". In modern society, advertisement is everywhereIn society, advertisement becomes the popular promotion's strategy which talked by all people.

There are many kinds of advertisement.Word of Mouth Advertisement,Newspaper Advertisement,Magazine Advertisement,Publics Service Advertisement, Television/Commercial Advertisement, Internet/Online Advertisement, Direct Mail Advertisement, Billboard Advertisement, Taxi, Cab or Bus Advertisement, Aerial Banner Advertisement, Radio Advertisement.

Cosmetics, also known as make-up, are substances or products used to enhance or alter the appearance or fragrance of the body. Many cosmetics are designed for use of applying to the face and hair. They are generally mixtures of chemical compounds; some being derived from natural sources (such as coconut oil), and some being synthetics.

The example of persuasive strategies in woman cosmetic Ethos: Ponds White Beauty Edisi Raisa

"Dulu aku pakai berbagai macam bedak dan krim untuk jadi lebih putih. Tapi malah bikin pucat. Akhirnya aku sadar, aku bisa lebih cantik dengan kulit putih merona, noda tersamarkan. Ponds White Beauty yang mengandung Pro.VB3 dan Ginseng Korea, bekerja hingga kedalam mencerahkan jutaan sel kulit dan menyamarkan noda hitam.Krim pencerah dengan penjualan no. 1 di Indonesia. 
" I used to wear some powders and creams to brighten my face, but it looks so pale. Now I know that i can be more beautiful with my flushed white and black spots obscured. Ponds White Beauty contains Pro VB3, Korean ginseng. Deep action to brighten and remove black spot.Lightening cream with sales number 1 in Indonesia".

This ads categorized as Ethos because there is a sentence " Lightening cream with sales number 1 in Indonesia " as the power of advertisement to persuade consumers.

Pathos :Ponds White Beauty Lightening Cream

“Jerawatku, noda hitam lagi.Bikin aku ngga percayadiri. Jadi ngga bisa jalan bareng teman. Dengan Ponds White Beauty Lightening Cream, yang meningkatkan warna kulit membuatnya semakin cerah. Sekarang aku pede jalan bareng teman".

“ My acne, black spot. Make me feel not confident. I can't hangout with my friends. With Ponds White Beauty Lightening Cream, light up my skin tone and make it more brighter. Now, I'm ready to hangout with my friends. This ads using more emotion to get the consumers attention. From this advertisement we know that the woman feel not confident to hangout with her friends but after using ponds white beauty she can handle it and ready to hangout.

Logos : New Garnier Light Complete 3 days program

“ New Garnier Light Complete 3 days program. 100 x lebih banyak vit C, Super Essence, dan Serum Krim, plus SPF 20.Untuk mengurangi jumlah bintik hitam dan mencerahkan warna kulit".

“ NewGarnier Light Complete 3 days program. 100 x more vit C, Super Essence, Serum Cream, SPF 20. To reduce the number of black spot and improve skin tone". This ads using ingredient of the product to convince the customers. So they believe that the product is good". 


\section{RESEARCH METHODOLOGY}

\section{Methodology}

A descriptive qualitative method used in this study, because the data of this research are in the form of spoken text. The researcher analyze through describing and explaining data based onpersuasive strategies by Aristotle theory. It's analyze how word, context, and utterances had significant role in persuasive technique.

Qualitative research is conducted through long-term contact with the field (Miles \& Huberman, 2001) elaborates that qualitative research is " interpretive". Qualitative research involves analysis of data such as words, for example interviews, transcript, document, video or even personal experience material such as journal. The data of this research are all the spoken text/the utterances from the advertisement in woman cosmetics of skin whitening product on television commercial. There are about fifty samples of woman cosmetics in skin whitening product from different brand. Those advertisements are in the form of video that taken from the official website of the product, youtube, and watching the advertisement in television

\section{DATA AND DATA ANALYSIS}

There are about fifty samples of woman cosmetics in skin whitening product from different brand. Those advertisements are in the form of video that taken from the official website of the product, youtube, and watching the advertisement in television.

After collected the data the researcher transcribed it in the form of sentences. After that the researcher translate the real utterances ( in the form of Indonesian to English ). And then, the researcher listed the utterances, according to the types of persuasive strategies by Aristotle. That is Ethos, Pathos and Logos. The researcher will explain and describing the utterances to get the data. There are about fifty samples of woman cosmetics in skin whitening product from different brand, like Wardah, Pond's, Garnier, Citra, Nourish Skin and Fair \& Lovely. Those advertisements are in the form of video that taken from the official website of the product, youtube, and watching the advertisement in television. 
Based on the data analysis it is found that out of fifty utterances, there were 32 utterances categorized as Ethos, 12 utterances as Pathos, and 6 utterances as Logos. The proportion of each category is presented in Table 4.1

Table 4.1 Types of Persuasive Strategies

\begin{tabular}{llll}
\hline No & $\begin{array}{l}\text { Types of } \\
\text { Strategies }\end{array}$ & Number & Percentage \\
\hline 1. & Ethos & 32 & 64 \\
2 & Pathos & 12 & 24 \\
3 & & 6 & 12 \\
\hline & Logos & & $\mathbf{1 0 0}$ \\
\hline
\end{tabular}

Examples of Ethos

(1) "Dulu aku pakai berbagai macam bedak dan krim untuk jadi lebih putih.

' I used to apply powders and cream to be more brighten.

Tapi malah bikin pucat. Akhirnya aku sadar, aku bisa lebih cantik dengan

But it looks pale. I realized that I can be more beautiful with

kulit putih merona, noda tersamarkan. Ponds White Beauty yang

flushed white skin, blemish taint. Ponds White Beauty with

mengandung Pro.VB3 dan Ginseng Korea, bekerja hingga ke dalam

Pro.VB3 and Korean Ginseng, work up to the inside

mencerahkan jutaan sel kulit dan menyamarkan noda hitam. Krim pencerah

enlighten millions of skin cells and disguise black stain . Lightning cream

dengan penjualan no. 1 di Indonesia..”

With sales no.1 in Indonesia.'

\section{Examples of Pathos}

(2) "Wah festival sakura, foto yuk. Kulit kamu cantik putih merona.

'Wow Sakura festival, let's take a picture. Your skin is beautiful white blushing. 
Kulitkusamku bisa ngga ya?Bisa dong.Kan ada Garnier SakuraWhite. can my dull skin do that? You can. With Garnier Sakura White.

Baru Garnier Sakura White Cream SPF 21.Dengan extra sakura +vit.B3 New Garnier Sakura White Cream SPF 21.With extra sakura + vit. B3 cerahkan kulit kusam hingga kedalam.Tampak putih cerah.Merona brighten dull skin to the inside. looks bright white. blushing hingga 60\%.Kulit kusammu bisa tampak putih cerah merona juga kan.” up to $60 \%$. Your dull skin can look bright white blush also right.'

(3) "Wajahmu cerah pengen deh punya wajah sepertimu. Abcd.Abcd? Ia.

' Your face is so bright. I want it too.Abcd.abcd? Yes

Fair \& lovely multivitamin abcd.Fair $\boldsymbol{n}$ lovely multivitamin.

Fair $n$ lovely multivitamin abcd. Fair n lovely multivitamin.

Mengandung allantoin a, vitamin b, vitamin c, d. dipakai setiap hari.

Contains allantoin a, vitamin b, vitamin c, d. Used every day.

Wajahmu cerah. Kamu pantas ada didepan kamera.

Your face is bright. You deserve to be in front of the camera.

Berkat mudan Fair \& lovely abcd."

Because of you and Fair \&Lovely abcd .'

It is found that they are two strategies use of Persuasive Strategies in advertisement. They are Elaboration Likelihood Model ( ELM ) and Heuristic Systematic Model ( HSM ). The process happen in ELM divided into Central Route and Peripheral Route. Process in HSM divided into Heuristically Processing and Systematic Processing.

The Elaboration Likelihood Model (Petty and Cacioppo 1981) is discussed as a framework for understanding attitude formation and change with regard to products and services. These two approaches to attitude formation and change can be classified under what Petty and Cacioppo $(1981 ; 1983)$ refer to in their Elaboration Likelihood Model (ELM) as central and peripheral routes to persuasion. 
Table 4.2 The Use of Strategies /The Elaboration Likelihood Model

\begin{tabular}{llll}
\hline No & Type Of Proces & Number & Percentage \\
\hline 1. & Central Route & 31 & 62 \\
& & & \\
2. & Peripheral Route & 19 & 38 \\
\hline Total & & $\mathbf{5 0}$ & $\mathbf{1 0 0}$ \\
\hline
\end{tabular}

Characteristics of Central Route:

- Relevant

- Any facts

- Give the composition from the product / Sometimes giving steps

Example of Central Route

(1) “Saya lebih menyukai kulit putih, dan kini kita bisa memilikinya.

' I prefer white skin, and now we can have it

Pakailah NBC bio white. Banyak kelebihannya. Whitening series.

Use NBC Bio white. Many advantages. Whitening series.

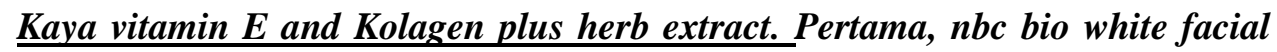
foam.

$\underline{\text { Rich of vitamin } \mathrm{E} \text { and Collagen plus herb extract. First, NBC bio white facial }}$ foam.

Yang mengangkat kotoran dan sel-sel kulit mati.Lalu, oleskan

That removes dirt and dead skin cells. Then, apply

NBC Bio white serum. Keduanya. Efektif merubah kulit gelap

nbc biowhite serum. Both. Effectively changing dark skin.

Menjadi terang.Kulit pun cerah putih berseri.

into light. The skin was bright white glow.

NBC bio white.White for me.White for you."

NBC bio white.White for me.White for you."

Characteristics of Peripheral Route: 
- Irrelevant

- No Facts

- No composition from the product

\section{Examples of Peripheral Route}

(2) “Awali cerahnya kulitmu dengan wardah white secret series,

' $\underline{\text { Start your bright skin with wardah white secret series, }}$

Kelembutan yang halal, sempurna untuk kau dan aku.”

Halal softness, perfect for you and me.

The Heuristic Systematic model (Craiken, 1980), also includes two modes of processing which is similar to the elaboration likelihood model. The two routes include 'systematic processing' this is effortful and comprehensive information processing of the message. The Heuristic Systematic Model (Craiken, 1980), is a widely recognized communication model that attempts to explain how people receive and process persuasive message. The model states that individuals can process message in two ways: Heuristically and Systematically.

Table 4.3 The Use of Strategies / Heuristics Systematic Model

\begin{tabular}{llll}
\hline No & Type Of Process & Number & Percentage \\
\hline 1. & Heuristically Processing & 12 & 24 \\
2. & Systematically Processing & 38 & 76 \\
\hline Total & & $\mathbf{5 0}$ & $\mathbf{1 0 0}$ \\
\hline
\end{tabular}

Characteristics of Heuristically Processing

- Message by expert / endorsed by Artist or friends

- Not always giving facts or composition from the product

- Sometimes only an argument. 


\section{Example of Heuristically Processing}

(1) "Nikita, apa sih rahasia suksesnya? Kita bisa meraih mimpi apapun.

' Nikita, what is your secret of success? We can achieve any dream.

Hadapi segalanya dengan percaya diri dan wajah cerah. Kamu enak

Face everything with confidence and bright faces. You have

Punya wajah cerah.Tapi kita?Gampang. Pakai yang banyak multi

a bright face.But we? Easy. Wear a lot of multi.

Vitamin. Multivitamin?Di wajahmu.Memperkenalkan fair \& lovely

Vitamin.Multivitamin? In your face. Introducingfair \& lovely

dengan multivitamin. Mencerahkan, menutrisi

with multivitamin. Brighten, nourish

dan membuat kulit wajah bercahaya. Untuk wajah

make glowing facial skin. For brightly

tampak cerah dan bersih. Masa depan cerah ada ditangan kita.”

Lookingface and clean. bright future is in our hands.'

Characteristics of Systematically Processing:

- Relevant

- Motivate the costumers

- Any facts

Examples of Systematically Processing

(2) “ Hai. Mau punya wajah lebih cerah untuk janji special weekend ini?

' Hi. Want to have a brighter face for this special weekend appointment? Garnier Light Complete program 3 hari dengan 100 kali vit.C. Step 1

Garnier Light Complete program 3 days with 100 times vit. C. Step 1 tepuk serum essence. Step 2 oles krim SPF. Satu dua tiga. Dalam tiga pat the essence serum. Step 2 smear the SPF cream. One two three. In three hari tampak lebih cerah. Baru Garnier Program 3 hari. Cobain aja.” days it looks brighter. New Garnier Program 3 days. Just try it.'

\section{Reason For The Use}

It is found that they are two reasons for the use of Persuasive Strategies in advertisement. They are Elaboration Likelihood Model( ELM ) and Heuristic 
Systematic Model ( HSM ). The process happen in ELM divided into Central Route and Peripheral Route. Process in HSM divided into Heuristically Processing and Systematic Processing.

The following texts are examples of Central Route

(1) "Pakailah NBC bio white. Banyak kelebihannya. Whitening series. Kaya vitamin C \& E dan Kolagen plus herb extract".

This ad use Central Route because from the utterances of the video this ad talk about the benefit of the product but also the composition or the true fact from the product for our face so we as a costumers can believe and want to buy that product.

The 'Peripheral' Route, this occurs when motivation and/or ability are relatively low and attitudes are determined by positive or negative cues. This is a way of influencing people by just giving low argument or fact about that product. Mostly with simple sentences with minimal data from the product and has no relevance between the product with the text or data that delivered in the ad. Example of the Peripheral Route are presented in the following texts

(2) " Awali cerahnya kulitmu dengan wardah white secret series, kelembutan yang halal, sempurna untuk kau dan aku."

This ad use Peripheral Route because they want to offering facial whitening product, but not provide clear data about the product. There's no fact, composition or the full benefit from the product, so it can't persuade the viewer from the ad and the costumers to buy the product.

(3) Nikita, apa sih rahasia suksesnya? Kita bisa meraih mimpi apapun. Hadapi segalanya dengan percaya diri dan wajah cerah. Kamuenak. Punya wajah cerah. Tapi kita? Gampang. Pakai yang banyak multi Vitamin. Multivitamin? Di wajahmu. Memperkenalkan fair \& lovely dengan multivitamin. Mencerahkan, menutrisi dan membuat kulit wajah bercahaya. Untuk wajah tampak cerah dan bersih. Masa depan cerah ada ditangan kita."

From the example that the ad was starring by an artist Nikita Willy. And when the people or her fans watching that ad, everyone just believes because 
when an artist uses that product it means that it's really good and without thinking twice directly affected to buy it.

The Heuristic Systematic Model (Craiken, 1980), is a widely recognized communication model that attempts to explain how people receive and process persuasive message. The model states that individuals can process message in two ways: Heuristically and Systematically.

Heuristically processing are likely to agree with message delivered by experts or message that are endorsed by others, or usually Artist or friends that want to sell the product to otherswithout fully processing the semantics content of the message.

(4) " Nikita, apa sih rahasia suksesnya? Kita bisa meraih mimpi apapun. Hadapi segalanya dengan percaya diri dan wajah cerah. Kamu enak. Punya wajah cerah.Tapi kita? Gampang. Pakai yang banyak multi Vitamin. Multivitamin? Di wajahmu. Memperkenalkan fair \& lovely dengan multivitamin. Mencerahkan, menutrisi dan membuat kulit wajah bercahaya. Untuk wajah tampak cerah dan bersih. Masa depan cerah ada ditangan kita."

From the example that the ad was starring by an artist Nikita Willy. And when the people or her fans watching that ad, everyone just believes because when an artist uses that product it means that it's really good and without thinking twice directly affected to buy it.

Actually the Systematic processing almost same with Central Route is were people think about arguments and elaborate on them.

(5) " Mau punya wajah lebih cerah untuk janji special weekend ini? Garnier Light Complete program 3 hari dengan 100 kali vit.C.

From this ad they give facts about the product and its benefit to the skin. Vit $\mathrm{C}$ is really good for skin. Especially skin face, Vit. C can handle the amount of black spot in our face and get rid of acne. So from this ad they give us strong persuasive to make everyone believe that the product is really good." 


\section{CONCLUSION AND SUGGESTION}

\section{Conclusions}

After analyzing the type of Persuasive Strategies in Woman Cosmetics Advertisement of skin whitening product on television commercials. The conclusions are as follow : conclusions are as follow :

(1) About fifty utterances that have been listed from the woman cosmetics advertisement there are three types of Persuasive Strategies of Woman Cosmetics in skin whitening product on Television Commercials according to Aristotle. That are Ethos, Pathos and Logos. There were 32 utterances that categorized as Ethos, 12 utterances categorized as Pathos, and 6 utterances categorized as Logos.

(2) Two process happened in persuasive strategies they are Elaboration Likelihood Model (ELM) and The Heuristic Systematic Model (HSM). Elaboration Likelihood Model consists of 'central route' and the 'peripheral' route. The central route is were people think about arguments and elaborate on them, they use motivation and the ability to scrutinize issue relevant arguments. The 'peripheral' route, this occurs when motivation and/or ability are relatively low and attitudes are determined by positive or negative cues. The Heuristic Systematic Model. The model states that individuals can process message in two ways: Heuristically and Systematically. Heuristically processing are likely to agree with message delivered by experts or message that are endorsed by others, or usually Artist or friends. Context of Systematically Processing, the ad must be relevant with the specific reason and relevant information, also response accordingly to the semantic content of the message.From this study the researcher found that were 31 utterances are Central Route as the process happen in ad and 19 utterances from the advertisement are Peripheral Route. Although the process happen in HSM Heuristicaly Processing 12 and Systematically Processing 38. 
(3) The reason for the use is the ways they are according to the examples of utterances from the woman cosmetics advertisement in television commercial. They are two reasons for the use is the way they are. First Elaboration Likelihood Model (ELM) that divided into Central and Peripheral and The Heuristic Systematic Model (HSM) divided into Heuristics and Systematically processing. Reason for it use depends from the use of word or utterances in the advertisement and it must be relevant with the characteristics of each reason.

\section{Suggestions}

In relation to the conclusions, some suggestions are given as following

1. The students of English Department especially to the literature students should learn more about the types and how persuasive can persuade others in many things. Especially in Advertisement. In order to add their knowledge and information about Persuasive Strategies so they can understand how persuasive work in advertisement

2. For the future researchers, it is suggested that the research of linguistics especially to do further studies on the types of persuasive strategies. It can be the reference to help them study about it. And also to found the new information or knowledge about the persuasive strategies that didn't found in this research before.

3. To the viewer or readers it is very important to help them to understand the meaning and types of persuasive strategies in advertisements. In order to add their knowledge and information about persuasive and how persuasive used in advertisement especially in woman cosmetics. 


\section{REFERENCES}

Boyland, Emma J. 2010. Persuasive Techniques Used in Television Advertisements to Market Foods to UK Children. UK:Department of Experimental Psychology, University of Liverpool .

Dimon, C \& Halloway, I. 2002 .Qualitative Research Method In Public Relation and Marketing Communication. London:Rouledge.

Fauzan. 2013. Persuasive Strategies used in Slogans of Cigarette's Advertisement. Unpublished Thesis Malang:Maulana Malik Ibrahim State University of Malang .

Izzah. 2012. Persuasive Strategies Used in Hillary Clinton's Political Campaign Speech. Unpublished Thesis.Malang : Maulana Malik Ibrahim State University of Malang. f, Go

Keraf Gorys. 2000. Argumentasi Dan Narasi. Jakarta:PT GRAMEDIA

Kotler, P. 2002. Advertising ( $\left.2^{\text {nd }} e d\right)$. New York:Jhn Willy and co.

Levine, Robert PhD. 2003. The Power of Persuasion : How We're Bough and Sold. Canada : John Wiley \& Sons, Inc.

Mulholland, J. 1994. Handbook of persuasive tactics : A practical language guide.London : Routledge

Mukkaromah, Nuckfi. Persuasive Strategies Used in Slogan of Iphone Advertisement. Unpublished Thesis.Malang : Maulana Malik Ibrahim State University of Malang.

O’Shaugnessy, John. 2004. Persuasion in Advertising. London:Routledge

Patpong, PattamaJor. 2008. Language of Persuasion: An Analysis of Selected Samples from Talisman Advertisements. Thailand:Institute of Language and Culture for Rural Development Mahidol University.

Safitri, I.2013.Persuasive Strategies of Commercial and Non Commercial Advertisement on Time Magazine.

S. A Kenechukwu. 2013. Behind Advertising: The Language Of Persuasion. Nigeria: Department of Mass Communication, Madonna University Okija .

Schmidt, Rosemarie \& J. F. Kess. 1986. Television advertising and televangelism. Amsterdam/Philadelphia : John Benjamin Publishing Company 
Scott, L. M \& R. Batra. 2003. Persuasive Imagery A Consumer Response Perspectif. USA : Lawrence Erlbaum Associates, Inc.

Thompson, Peter. 1998. Persuading Aristotle. Australia:The Electric Book Company. 